\title{
Changes in religious beliefs and the relation of religiosity to posttraumatic stress and life satisfaction after a natural disaster
}

\author{
Ajmal Hussain · Lars Weisaeth · Trond Heir
}

Received: 25 September 2009/Accepted: 2 July 2010/Published online: 31 July 2010

(C) The Author(s) 2010. This article is published with open access at Springerlink.com

\begin{abstract}
Objective To study changes in religious beliefs and predictors of such changes in a community sample exposed to a natural disaster, and to investigate whether religiosity was linked to post-disaster mental distress or life satisfaction.

Methods An adult population of 1,180 Norwegian tourists who experienced the 2004 tsunami was surveyed by a postal questionnaire 2 years after the disaster. Data included religiosity, disaster exposure, general psychopathology, posttraumatic stress and life satisfaction.

Results Among the respondents, 8\% reported strengthening and 5\% reported weakening of their religious beliefs. Strengthening was associated with pre-tsunami mental health problems (OR: 1.82, 95\% CI: 1.12-2.95) and posttraumatic stress (OR: 1.62, 95\% CI: 1.22-2.16). Weakening was associated with younger age (OR: $0.98,95 \% \mathrm{CI}$ : 0.96-1.00) and posttraumatic stress (OR: 1.72, 95\% CI: 1.23-2.41). Two years after the tsunami, $11 \%$ of the sample considered themselves to be positively religious. There were no significant differences in posttraumatic stress, general psychopathology or life satisfaction between religious and non-religious groups.

Conclusions Religion did not play an important role in the lives of Norwegian tsunami survivors in general. Respondents who had the greatest disaster exposure were more likely to report changes in religious beliefs in both
\end{abstract}

A. Hussain $(\bowtie) \cdot$ L. Weisaeth · T. Heir

Norwegian Centre for Violence and Traumatic Stress Studies, Kirkeveien 166, Building 48, 0407 Oslo, Norway

e-mail: ajmal.hussain@nkvts.unirand.no; ajmal@hussain.no

L. Weisaeth

Faculty of Medicine, University of Oslo, 0318 Oslo, Norway directions. Religious beliefs did not prevent post-disaster long-term mental distress, and religiosity was not related to higher levels of life satisfaction.

Keywords Norwegian tourist · 2004 tsunami · Changes in religious beliefs - Religiosity .

Posttraumatic stress

\section{Introduction}

Traumatic events affect not only the psychological dimension of the self, but also the faith system that gives meaning to life [40]. Religious beliefs can develop through the experience of traumatic events, and religion and spiritual beliefs can be helpful in psychological recovery [37]. Traumatic experiences sometimes enhance religious beliefs [7] or lead to an increase in religious activity [35]; alternatively, such experiences can result in a weakening of religious commitment [36] or even abandonment of religious faith [11].

Religion has often been perceived as a source of comfort, meaning and purpose for individuals who experience traumatizing life events [8, 34]. For many people, religion can make suffering understandable and bearable [32], and provides a means of coping in times of extreme stress [30, 31]. There have been many studies of religious coping [20] and of the relationship between religiosity and mental health $[16,18,27]$. The findings are somewhat inconclusive, although most report that religious commitment is related to better mental health [29]. Most of the studies are from the USA where religion seems to play an important role both at the community level $[12,26]$ and in the lives of many victims [34]. Also, the literature on the religionhealth connection has focused almost exclusively on 
religion as predictor of health resulting in few studies where religiosity is used as an outcome measure [24].

In many European countries, religion plays a secondary role in daily life activities [19]. According to an international Gallup survey [15], the Norwegians are among the least religious people in Europe. Although the majority of Norwegians are members of the state church, religiosity does not impact on the daily lives of most individuals. Yet, attendance to religious ceremonies and participation in memorial services were striking among Norwegians in the aftermath of the 2004 tsunami. Such collective ritual response has also been described in the acute phase after major accidents in Norway [9]. However, it is unclear what role religion plays in the lives of Norwegian trauma victims in the long run and whether major disasters can induce enduring changes in religious beliefs.

In the present study, we explored the association of characteristics of survivors of a natural disaster and their religious beliefs. We specifically address four questions. First, what is the prevalence of changes in the strength of religious faith following the 2004 tsunami in Norwegian tourists? Second, what factors predict these changes? Third, does religion play an important role in the lives of the tsunami survivors 2 years after the disaster? And finally, are there any differences regarding posttraumatic stress, general psychopathology and life satisfaction between those who report that religion is a source of strength and those who do not?

\section{Methods}

Study sample and design

The 2004 southeast Asia tsunami was one of the largest tragedies in recent history with a death toll of 226,408 (Centre for Research on the Epidemiology of Disasters, de Louvain, Belgium, e-mail of 25 June 2008). In the days following the disaster, all Norwegian tourists were repatriated from disaster-affected countries and registered by the police upon their arrival in Norway. To investigate the long-term mental health aspects, 2 years after the tsunami a questionnaire was mailed to all registered individuals over the age of 18 years at the time of the disaster $(N=2,468)$. The questionnaire was returned by 1,180 survivors $(49.3 \%$ response rate, 76 persons not located). The average current age of respondents was 45.0 years $(\mathrm{SD}=12.9) ; 49.2 \%$ were men, $58.2 \%$ had $\geq 13$ years of education, $68.5 \%$ were currently married or cohabitating and $73 \%$ were employed. The reported lifetime prevalence of contact with a general practitioner, psychologist or psychiatrist for mental health concerns was $23.3 \%$ prior to the tsunami.
Most respondents had been exposed to the tsunami as threat to their lives and/or horrific witness experiences [22].

We investigated lack of participation with follow-up telephone interviews in a random sample of non-participants $(n=171)$ [25]. Non-participants did not differ significantly from participants in terms of age and gender, but they reported lower levels of disaster exposure and lower levels of posttraumatic stress symptoms. The most frequently reported reasons for not participating in the study were lack of interest or time (39.2\%) and not being directly affected by the disaster $(32.2 \%)$.

The study was approved by the regional committee for medical research ethics and by the Norwegian Social Science Data Services.

Measures

\section{Religiosity}

Changes in religious beliefs were measured by a question from the 'Religious Outcome Scale' [33]: do you feel that you have become more religious after the tsunami? Subjects were asked to answer this question using a five-point scale: $1=$ much more religious; $2=$ somewhat more religious; $3=$ no change; $4=$ somewhat less religious; $5=$ much less religious. Responses 1 and 2 were considered as strengthening of religious beliefs, while responses 4 and 5 were considered as weakening of religious beliefs.

Religiosity at the time of the study ("current religiosity”) was measured by a question from Zuckerman's threeitem Index of Religiousness [41]: how much is religion a source of strength and comfort to you? Responses were coded on a four-point scale ranging from 1 (= "none") to 4 (= "a great deal"). Responses 1 and 2 were considered to indicate that the respondent was less religious (labeled nonreligious), while responses 3 and 4 were considered to indicate that the respondent was positively religious (labeled religious).

Both questions concerning religion addressed personal feelings of religiosity rather than attachment to a religious community or participation in religious activities. Thus, the questions were applicable to all the respondents regardless of their specific belief system.

\section{Disaster exposure}

Respondents were asked about the degree to which they perceived that their life had been threatened by the tsunami, whether a close relative or friend died in the tsunami, and whether they sustained physical injuries from the tsunami. In a previous study of Norwegian tsunami survivors, the life threat intensity was the best predictor of health complaints [23]. 
Posttraumatic stressors and symptoms

The "List of Threatening Experiences, questionnaire version (LTE-Q)" [4] was used to assess additional stress experienced after the tsunami. This instrument measures 12 adverse life events during the previous year that carry significant long-term threat.

Current posttraumatic stress symptoms were measured using the Impact of Event Scale-Revised (IES-R) [39]. The IES-R is a 22-item self-report measure of subjective distress following exposure to traumatic events. Symptom severity was measured according to the original IES-R by five response anchors $(0=$ not at all, $1=$ a little bit, $2=$ moderately, $3=$ quite a bit and $4=$ extremely), as experienced in the previous 7 days.

The General Health Questionnaire (GHQ-28) [17], scored on a four-point Likert scale $(0,1,2,3)$, was used as a measure of general psychopathology.

Life satisfaction was measured with Cantril's Ladder of Life (LOL) [6] which consists of ten steps. The top rung of the ladder (10) represents the best possible life imaginable and the bottom rung (1) represents the worst possible life. Respondents were instructed to write the number of the step on which they felt they currently stood.

\section{Statistics}

Bivariate logistic regression analyses were used to determine associations between demographic and background variables, disaster exposure, current posttraumatic stress symptoms and dependent variables such as strengthening of religious beliefs (versus not) or weakening of religious beliefs (versus not). Odds ratio was used as measure of the strength of an association. Multivariate logistic regression analysis was used to determine the adjusted effects of predictors of changes in religious beliefs, controlled for age and gender. All variables that were significant in bivariate analyses were entered in the multivariate regression model. Bivariate analyses were performed using $t$ tests (continuous variables) and Chi-square tests (categorical variables) to compare the religious and the non-religious respondent groups according to demographic and exposure variables. Multiple linear regression analyses were performed to assess the relationship between religiosity and measures of posttraumatic stress (IES-R), general psychopathology (GHQ-28) and life satisfaction (LOL), while adjusting for other significant variables.

All analyses were conducted using the software Statistical Package for the Social Sciences (SPSS, version 16.0). $P$ values $<0.05$ were considered to be significant.

\section{Results}

The majority of responding Norwegian tourists, $86.5 \%$ ( $n=1,005)$ reported no change in their religious beliefs following the tsunami, $97(8.3 \%)$ reported strengthening of religious beliefs and $60(5.2 \%)$ reported weakening. Strengthening of religious beliefs was bivariately associated with pre-tsunami mental health problems, life threat intensity as experienced during the tsunami, loss of a family member or close friend, inflicted injuries, posttraumatic stress and post-tsunami adverse life events (Table 1).

A multivariate logistic regression model revealed that strengthening of religious beliefs remained significantly associated with pre-tsunami mental health problems (OR: 1.82, 95\% CI: $1.12-2.95, P=0.015)$ and with posttraumatic stress (OR: $1.62,95 \% \mathrm{CI}: 1.22-2.16, P=0.001$ ).

Weakening of religious beliefs was bivariately associated with younger age, life threat intensity, posttraumatic stress and post-tsunami adverse life events (Table 2).

A multivariate logistic regression model showed that weakening of religious beliefs remained significantly associated with younger age (OR: 0.98, 95\% CI: 0.96-1.00, $P=0.047$ ) and posttraumatic stress (OR: $1.72,95 \% \mathrm{CI}$ : 1.23-2.41, $P=0.002$ ).

A minority of the study population $(10.8 \%)$ reported that religion was an important source of personal strength and comfort (positively religious). Religiosity was associated with female sex, older age, unemployment, and pretsunami mental health problems, but not with exposure (analyses not shown). There were no significant differences between the religious and the non-religious groups regarding posttraumatic stress, general psychopathology and life satisfaction (Table 3).

Also when controlling for potential confounders such as gender, age, unemployment, and pre-tsunami mental health problems, no significant association between religiosity and posttraumatic stress, general psychopathology or life satisfaction were found.

\section{Discussion}

Our results showed bidirectional changes in religious beliefs in Norwegian disaster survivors 2 years after the 2004 southeast Asian tsunami. To the authors' knowledge, no other study has examined changes in religious beliefs after a natural disaster. However, similar changes have been reported in studies after other types of traumas [11, 13, 14, 38]. In the present study, there was less change in religious beliefs compared to populations of potentially traumatized individuals with prolonged exposure, such as US war veterans [11, 14] and cancer patients 
Table 1 Overview of bivariate logistic regression analyses conducted to determine general associations between becoming more religious and demographic variables, exposure variables and current posttraumatic stress

\begin{tabular}{llll}
\hline Total & More religious & Odds ratio \\
$N$ & $n(\%)$ or mean & \\
\hline
\end{tabular}

\section{Gender}

Male

Female

Missing

Age (years) ${ }^{\mathrm{a}}$

Missing

$N$

$n(\%)$ or mean

Education

$$
\begin{aligned}
& <13 \text { years } \\
& \geq 13 \text { years } \\
& \text { Missing }
\end{aligned}
$$

$56841(7.2)$

$594 \quad 56(9.4)$

1,162

41.9 vs. 41.7

1.00

Married or cohabiting ${ }^{\text {a }}$

$\begin{array}{lr}\text { Yes } & 816 \\ \text { No } & 327 \\ \text { Missing } & 36 \\ \text { Employed }^{\text {a }} & \\ \text { Yes } & 922 \\ \text { No } & 240 \\ \text { Missing } & 17\end{array}$

Pre-tsunami mental health problems

$\begin{array}{lrr}\text { No } & 870 & 60(6.9) \\ \text { Yes } & 275 & 35(12.7) \\ \text { Missing } & 34 & \end{array}$

$74(8.0)$

$240 \quad 23(9.6)$

Life threat intensity

$\begin{array}{llll}\text { None } & 335 & 14(4.2) & \\ \text { Small/moderate } & 415 & 28(6.7) & 1.66 \\ \text { Great/overwhelming } & 311 & 47(15.1) & 4.08^{* *} \\ \text { Missing } & 118 & & \end{array}$

Loss of family members or close friends

$\begin{array}{lrll}\text { No } & 1,079 & 81(7.5) & \\ \text { Yes } & 79 & 15(19.0) & 2.89^{* *} \\ \text { Missing } & 21 & & \\ \text { Physical injury } & & & \\ \text { No } & 1,002 & 71(7.1) & \\ \text { Yes } & 141 & 25(17.7) & 2.83^{* *} \\ \text { Missing } & 36 & & \end{array}$

Post-tsunami adverse life events

$\begin{array}{lrll}\text { No } & 436 & 24(5.5) & \\ \text { Yes } & 714 & 73(10.2) & 1.96^{* *} \\ \text { Missing } & 29 & & \\ \text { IES-R }{ }^{\mathrm{b}} \text { (mean item score) } & 1,158 & 0.90 \text { vs. } 1.55 & 2.21^{* *} \\ \quad \text { Missing } & 21 & & \end{array}$

$* P<0.01$

$* * P<0.001$

a At the time of the disaster

b Impact of event scale-revised
Table 2 Overview of bivariate logistic regression analyses conducted to determine general associations between becoming less religious and demographic variables, exposure variables and current posttraumatic stress

\begin{tabular}{lll}
\hline Total & Less religious & Odds ratio \\
$N$ & $n(\%)$ or mean & \\
\hline
\end{tabular}

\section{Gender}

Male

Female

$568 \quad 35(6.2)$

Missing

$594 \quad 25(4.2)$

0.67

Age (years) ${ }^{\mathrm{a}}$

Missing

$1,162 \quad 42.1$ vs. 38.6

$0.98^{*}$

Education

$\begin{array}{lrrr}<13 \text { years } & 466 & 28(6.0) & \\ \geq 13 \text { years } & 676 & 30(4.4) & 0.73 \\ \text { Missing } & 37 & & \end{array}$

Married or cohabiting ${ }^{\mathrm{a}}$

Yes

$816 \quad 38(4.7)$

No

$327 \quad 21(6.4)$

1.41

Missing

36

Employed $^{\mathrm{a}}$

Yes $\quad 922 \quad 47(5.1)$

No $\quad 240 \quad 13(5.4)$

0.94

Missing

17

Pre-tsunami mental health problems

$\begin{array}{lrrr}\text { No } & 870 & 44(5.1) & \\ \text { Yes } & 275 & 15(5.5) & 1.08 \\ \text { Missing } & 34 & & \\ \text { Life threat intensity } & & & \\ \text { None } & 335 & 10(3.0) & \\ \text { Small/moderate } & 415 & 23(5.5) & 1.91 \\ \text { Great/overwhelming } & 311 & 22(7.1) & 2.47^{*} \\ \text { Missing } & 118 & & \end{array}$

Loss of family members or close friends

\begin{tabular}{lrll} 
No & 1,079 & $54(5.0)$ & \\
Yes & 79 & $5(6.3)$ & 1.28 \\
Missing & 21 & & \\
Physical injury & & & \\
No & 1,002 & $48(4.8)$ & 1.52 \\
Yes & 141 & $10(7.1)$ & \\
Missing & 36 & & \\
Post-tsunami adverse life events & & \\
No & 436 & $14(3.2)$ & \\
Yes & 714 & $46(6.4)$ & \\
Missing & 29 & & \\
IES-R & & \\
Missing & 1,158 & 0.93 vs. 1.41 & \\
\hline
\end{tabular}

$* P<0.05$

** $P<0.001$

a At the time of the disaster

b Impact of event scale-revised 
Table 3 Comparing religious and non-religious respondent groups ( $t$ test) according to life satisfaction (LOL), general psychopathology (GHQ-28) and posttraumatic stress (IES-R)

\begin{tabular}{llll}
\hline & $\begin{array}{l}\text { Religious } \\
\text { group } \\
n=128\end{array}$ & $\begin{array}{l}\text { Non-religious } \\
\text { group } \\
n=1,133\end{array}$ & $P$ values \\
\hline $\begin{array}{l}\text { LOL }^{\mathrm{a}} \\
\text { Mean score }\end{array}$ & $7.38(\mathrm{SD}=1.92)$ & $7.28(\mathrm{SD}=1.85)$ & 0.58 \\
GHQ-28 & \\
$\begin{array}{l}\text { Mean total score } \\
\text { IES-R }\end{array}$ & $26.2(\mathrm{SD}=14.3)$ & $24.3(\mathrm{SD}=13.4)$ & 0.22 \\
Mean total score & $24.0(\mathrm{SD}=19.2)$ & $20.7(\mathrm{SD}=18.2)$ & 0.06 \\
\hline${ }^{\mathrm{a}}$ Ladder of life & & \\
${ }^{\mathrm{b}}$ General health questionnaire & & \\
${ }_{\mathrm{c}}$ Impact of event scale-revised &
\end{tabular}

with ongoing threat of life [38]. There was also less change in our study population than in a mixture of US community and mental health treatment samples that had experienced various potentially traumatizing events [13]. The respondents in the present study experienced the tsunami as a distinct and time-limited stressful event. Due to repatriation to safe and stable communities in Norway, they escaped the typical burden of secondary disaster stressors. Thus, the lower prevalence of change in religious belief may be due to the particular type, magnitude and duration of exposure [34].

Posttraumatic stress was the main predictor of both strengthening and weakening of religious beliefs. This is in agreement with some previous studies [13], but not with others [14]. Post-disaster stress may be a confounder for severe disaster exposure, which could be the real cause of religious changes or it may have triggered changes in religious beliefs by itself $[1,13]$. It has been suggested that greater spirituality may develop as a coping mechanism in response to personal suffering [10]. Also, personal growth in general may follow trauma and subsequent struggle with adversity $[5,28]$.

Respondents with pre-tsunami mental health problems were more likely to report strengthening of religious beliefs. It is possible that previous mental health problems evoked spiritual or existential interests at an earlier stage of life $[2,3]$. When coping with the tsunami, a strengthening of religious belief may have been more likely among those who had previously used religion as part of a coping strategy [32].

No differences were found in life satisfaction or general psychological distress between the religious and non-religious survivors. This does not support the general idea that religiosity prevents long-term mental stress [18, 24, 37] or leads to higher life satisfaction [18, 20, 27].

\section{Limitations}

The cross-sectional study design did not allow us to draw conclusions about cause-effect relationships. Use of single item measures limits an in-depth understanding of the findings given the complex construct of religiosity [24]. Also, caution should be exercised in generalizing our findings, which may be limited to populations who experience traumatic events with a sudden impact and relatively brief exposure.

The representativeness of the population in terms of religion may be questioned as participants had chosen to celebrate their Christmas holiday abroad in a non-Christian country. However, more than $90 \%$ of the Norwegian tsunami survivors were in Thailand, where Christmas is celebrated in tourist resorts and also by the Norwegian Church Abroad. Further, the participants were similar to the ageand gender-adjusted Norwegian population with regard to employment and marital status [21].

\section{Conclusion}

We found a bidirectional change in religious beliefs among a minority of the tourists who experienced the 2004 tsunami; changes in religious beliefs were more common among respondents who had the greatest disaster exposure. Our findings did not support the hypothesis that religious beliefs prevent long-term posttraumatic stress, and religiosity was not associated with higher levels of life satisfaction. Future studies should focus on repeated measures of religiosity, posttraumatic stress and life quality to examine religious stability, changes in religious beliefs and cause-effect relationships.

Acknowledgments The study was funded by the Research Council of Norway.

Open Access This article is distributed under the terms of the Creative Commons Attribution Noncommercial License which permits any noncommercial use, distribution, and reproduction in any medium, provided the original author(s) and source are credited.

\section{References}

1. Ai AL, Park CL (2005) Possibilities of the positive following violence and trauma: informing the coming decade of research. J Interpers Violence 20:242-250

2. Baetz M, Griffin R, Bowen R, Koenig HG, Marcoux E (2004) The association between spiritual and religious involvement and depressive symptoms in a Canadian population. J Nerv Ment Dis 192:818-822

3. Blazer DG (2007) Section introduction: spirituality, depression and suicide. South Med J 100:733-734 
4. Brugha TS, Cragg D (1990) The list of threatening experiences: the reliability and validity of a brief life events questionnaire. Acta Psychiatr Scand 82:77-81

5. Calhoun LG, Tedeschi RG (2006) The handbook of posttraumatic growth: research and practice. Lawrence Erlbaum, Mahwah

6. Cantril H (1965) The pattern of human concerns. Rutgers University Press, New Brunswick

7. Carmil D, Breznitz S (1991) Personal trauma and world view: are extremely stressful experiences related to political attitudes, religious beliefs, and future orientation? J Trauma Stress 4:393-405

8. Chen YY, Koenig HG (2006) Traumatic stress and religion: is there a relationship? A review of empirical findings. J Relig Health 45:371-381

9. Danbolt LJ, Stifoss-Hanssen H (2007) [Memorial services after major accidents] [Article in Norwegian, English abstract]. Tidsskr Nor Laegeforen 127:157-160

10. Davidson JR, Connor KM, Lee LC (2005) Beliefs in karma and reincarnation among survivors of violent trauma: a community survey. Soc Psychiatr Epidemiol 40:120-125

11. Drescher KD, Foy DW (1995) Spirituality and trauma treatment: suggestions for including spirituality as a coping resource. NCP Clin Q 5:4-5

12. Edlund MJ, Harris KM, Koenig HG, Han X, Sullivan G, Mattox R, Tang L (2009) Religiosity and decreased risk of substance use disorders: is the effect mediated by social support or mental health status? Soc Psychiat Epidemiol (Published online ahead of print Aug 28, 2009)

13. Falsetti SA, Resick PA, Davis JL (2003) Changes in religious beliefs following trauma. J Trauma Stress 16:391-398

14. Fontana A, Rosenheck R (2004) Trauma, change in strength of religious faith, and mental health service use among veterans treated for PTSD. J Nerv Ment Dis 192:579-584

15. Gallup International. Religiosity around the World VoP 05 Press release. http://www.voice-of-the-people.net/. Accessed 3 Sep 2009

16. Gartner J, Larson DB, Allen GD (1991) Religious commitment and mental health: a review of the empirical literature. J Psychol Theol 19:6-25

17. Goldberg DP, Hillier VF (1979) A scaled version of the General Health Questionnaire. Psychol Med 9:139-145

18. Hackney CH, Sanders GS (2003) Religiosity and mental health: a meta-analysis of recent studies. J Sci Stud Relig 42:43-55

19. Halman L, Draulans V (2006) How secular is Europe? Br J Sociol 57:263-288

20. Harrison MO, Koenig HG, Hays JC, Eme-Akwari AG, Pargament KI (2001) The epidemiology of religious coping: a review of recent literature. Int Rev Psychiatry 13:86-93

21. Heir T, Piatigorsky A, Weisaeth L (2009) Longitudinal changes in recalled perceived life threat after a natural disaster. $\mathrm{Br} \mathrm{J}$ Psychiatry 194:510-514

22. Heir T, Sandvik L, Weisaeth L (2009) Hallmarks of posttraumatic stress: symptom $z$ scores in a tsunami-affected tourist population. Psychopathology 42:157-164

23. Heir T, Weisaeth L (2008) Acute disaster exposure and mental health complaints of Norwegian tsunami survivors six months post disaster. Psychiatry 71:266-276
24. Hill PC, Pargament KI (2003) Advances in the conceptualization and measurement of religion and spirituality: implications for physical and mental health research. Am Psychol 58:64-74

25. Hussain A, Weisaeth L, Heir T (2009) Nonresponse to a population-based postdisaster postal questionnaire study. J Trauma Stress 22:324-328

26. Idler EL, Musick M, Ellison CG, George LK, Ory M, Pargament KI, Powell LH, Underwood L, Williams D (2001) Measuring multiple dimensions of religion and spirituality for health research: conceptual background and findings from the 1998 general social survey. GSS topical report no. 33, July 2001

27. Koenig HG, Larson DB (2001) Religion and mental health: evidence for an association. Int Rev Psychiatry 13:67-78

28. Linley PA, Joseph S (2004) Positive change following trauma and adversity: a review. J Trauma Stress 17:11-21

29. Matthews DA, McCullough ME, Larson DB, Koenig HG, Swyers JP, Milano MG (1998) Religious commitment and health status: a review of the research and implications for family medicine. Arch Fam Med 7:118-124

30. Niaz U (2006) Role of faith and resilience in recovery from psychotrauma. Pak J Med Sci 22:204-207

31. Overcash WS, Calhoun LG, Cann A, Tedeschi RG (1996) Coping with crises: an examination of the impact of traumatic events on religious beliefs. J Genet Psychol 157:455-464

32. Pargament KI (1997) The psychology of religion and coping: theory, research, practice. Guilford Press, New York

33. Pargament KI, Ensing KF, Olsen H, Reilly B, van Haitsma K, Warren R (1990) God help me: (I): Religious coping efforts as predictors of the outcomes to significant negative life events. Am J Commun Psychol 18:798-824

34. Park CL (2005) Religion as a meaning-making framework in coping with life stress. J Soc Issues 61:707-729

35. Schuster MA, Stein BD, Jaycox L, Collins RL, Marshall GN, Elliott MN, Zhou AJ, Kanouse DE, Morrison JL, Berry SH (2001) A national survey of stress reactions after the September 11, 2001, terrorist attacks. N Engl J Med 345:1507-1512

36. Schwartzberg SS, Janoff-Bulman R (1991) Grief and the search for meaning: exploring the assumptive worlds of bereaved college students. J Soc Clin Psychol 10:270-288

37. Shaw A, Joseph S, Linley PA (2005) Religion, spirituality, and posttraumatic growth: a systematic review. Ment Health Relig Cult 8:1-11

38. Torbjørnsen T, Stifoss-Hanssen H, Abrahamsen AF, Hannisdal E (2000) Cancer and religiosity - a follow up of patients with Hodgkin's disease [Article in Norwegian, English abstract]. Tidsskr Nor Laegeforen 120:346-348

39. Weiss DS (2004) The impact of event scale-revised. In: Wilson JP, Keane TM (eds) Assessing psychological trauma and PTSD, 2nd edn. Guilford, New York

40. Wilson JP, Moran TA (1998) Psychological trauma: posttraumatic stress disorder and spirituality. J Psychol Theol 26:168-178

41. Zuckerman DM, Kasl SV, Ostfeld AM (1984) Psychosocial predictors of mortality among the elderly poor: the role of religion, well-being, and social contacts. Am J Epidemiol 119:410-423 